\title{
Snow-Pit Record from a Coastal Antarctic Site and Its Preservation of Meteorological Features
}

\author{
YAlalt Nyamgerel, ${ }^{\mathrm{a}, \mathrm{b}}$ SANG-Bum Hong, ${ }^{\mathrm{b}}$ YeOngCheOl Han, ${ }^{\mathrm{b}}$ Songyi Kim, ${ }^{\mathrm{a}, \mathrm{b}}$ JeONGHOON Lee, ${ }^{\mathrm{a}}$ \\ AND SOON DO HUR ${ }^{\mathrm{b}}$ \\ ${ }^{a}$ Department of Science Education, Ewha Womans University, Seoul, South Korea \\ ${ }^{\mathrm{b}}$ Division of Glacial Environment Research, Korea Polar Research Institute, Incheon, South Korea
}

(Manuscript received 22 September 2020, in final form 19 May 2021)

\begin{abstract}
Polar snow pits or ice cores preserve valuable information derived from the atmosphere on past climate and environment changes. A 1.57-m snow-pit record from the coastal site (Styx Glacier) in eastern Antarctica covering the period from January 2011 to January 2015 was discussed and compared with meteorological variables. The dominant contribution of the deposition of sea-salt aerosols due to the proximity of the site to the ocean and processes of sea ice formation was revealed in the ionic concentrations. Consistent seasonal peaks in $\delta^{18} \mathrm{O}, \delta \mathrm{D}, \mathrm{MSA}, \mathrm{nssSO}_{4}^{2-}$, and $\mathrm{NO}_{3}^{-}$ indicate the strong enhancement of their source during warm periods, whereas the sea-salt ions $\left(\mathrm{Na}^{+}, \mathrm{K}^{+}, \mathrm{Mg}^{2+}, \mathrm{Ca}^{2+}, \mathrm{Cl}^{-}\right.$, and totSO ${ }_{4}^{2-}$ ) exhibit a distinct distribution. Monthly mean $\delta^{18} \mathrm{O}$ positively correlates with the air temperature record from an automatic weather station (AWS) located in the main wind direction. Despite the shortness of the record, we suspect that the slight depletion of the isotopic composition and lowering of the snow accumulation could be related to the cooler air temperature with the decrease of open sea area. Consistency with previous studies and the positive correlation of sea-salt ions in the snow pit indicate the relatively good preservation of snow layers with noticeable climate and environmental signals [e.g., changes in sea ice extent (SIE) or sea surface temperature]. We report a new snow-pit record, which would be comparative and supportive to understand similar signals preserved in deeper ice cores in this location.
\end{abstract}

KEYWORDS: Antarctica; Sea ice; Snow

\section{Introduction}

Polar precipitation in the form of snow and its subsequent accumulation retrieved from ice cores have been used as historical evidence to interpret past climatic and environmental conditions (Dansgaard 1964; Jouzel and Masson-Delmotte 2010). The highly resolved records in snow pits provide more precise information of climate and environment. Distinguishable seasonal patterns in the records of stable water isotopes $\left(\delta^{18} \mathrm{O}\right.$ and $\left.\delta \mathrm{D}\right)$ and chemical impurities are crucial for the stratigraphic dating of accumulated snow layers and are used as proxies for temperature, sea ice extent (SIE), atmospheric circulation, aerosol transport and depositional processes, and atmospheric (anthropogenic) pollution in this remote location (Udisti 1996; Jouzel et al. 1997; Barbante et al. 1998; Udisti et al. 1999; Stenni et al. 2000; Delmotte et al. 2000; Ayling and McGowan 2006; Sinclair et al. 2010; Rhodes et al. 2012; Markle et al. 2012; Tuohy et al. 2015; Du et al. 2019; Bhardwaj and Jindal 2020).

The isotopic and chemical compositions of snow, firn, and ice cores near to Victoria Land in East Antarctica have been reported, and they highlighted the possibility of reconstructing the influence of the oceanic environment (Udisti et al. 1998; Stenni et al. 2000; Benassai et al. 2005; Sinclair et al. 2014; Caiazzo et al. 2016). A repetitive seasonal (austral spring and summer) variation has been identified in $\delta^{18} \mathrm{O}, \delta \mathrm{D}, \mathrm{CH}_{3} \mathrm{SO}_{3}^{-}$[methanesulfonic acid

Corresponding author: Jeonghoon Lee, jeonghoon.d.lee@gmail.com

Earth Interactions is published jointly by the American Meteorological Society, the American Geophysical Union, and the Association of American Geographers.
(MSA)], non-sea-salt (nss) sulfate, and $\mathrm{NO}_{3}^{-}$in snow layers in the northern Victoria Land of East Antarctica (Udisti et al. 1998; Stenni et al. 2000; Rhodes et al. 2012; Becagli et al. 2016; Ro et al. 2020). Previous studies in the Styx Glacier covered the period of 1974-90 in firn cores (Stenni et al. 2000) and 2009-11 in snow pits (Kwak et al. 2015). More recently, Nyamgerel et al. (2020) focused on the temporal variations (1990-2014) of the stable isotopes and ions in the firn core with annual resolution.

Because of the significant spatial and temporal variabilities in Antarctic snowfall and temperature (Ingólfsson et al. 2003; Anschütz et al. 2011; Frezzotti et al. 2007; Masson-Delmotte et al. 2008; Yang et al. 2018) and the sparse collection of weather stations (Stenni et al. 2000; Tuohy et al. 2015), there are still limitations on the interpretation of paleoclimate records. Caiazzo et al. (2016) stated that the temporal variability more directly corresponds to real environmental changes rather than spatial variability of the site. Thus, site-based information and evaluation of isotopic and chemical compositions are required to investigate the present-day snow compositions and their differences at regional and/or local scales in addition to application to the interpretation of the paleoclimate records (Stenni et al. 2000; Ingólfsson et al. 2003; Tuohy et al. 2015; Stenni et al. 2017).

During the 2014/15 Antarctic expedition by the Korea Polar Research Institute (KOPRI), samples from a 1.57-m snow pit were taken from the Styx Glacier as a part of the research on paleoclimatic and environmental reconstruction along the Pacific margin of Antarctica. The purpose of this study is to evaluate the isotopic $\left(\delta^{18} \mathrm{O}\right.$ and $\left.\delta \mathrm{D}\right)$ and ionic composition $\left(\mathrm{Na}^{+}, \mathrm{K}^{+}, \mathrm{Mg}^{2+}, \mathrm{Ca}^{2+}, \mathrm{MSA}, \mathrm{Cl}^{-}, \mathrm{NO}_{3}^{-}\right.$, and $\left.\mathrm{SO}_{4}^{2-}\right)$ of the snow pit by comparing with instrumental meteorological variables on the seasonal scale. It is beneficial to understand the 


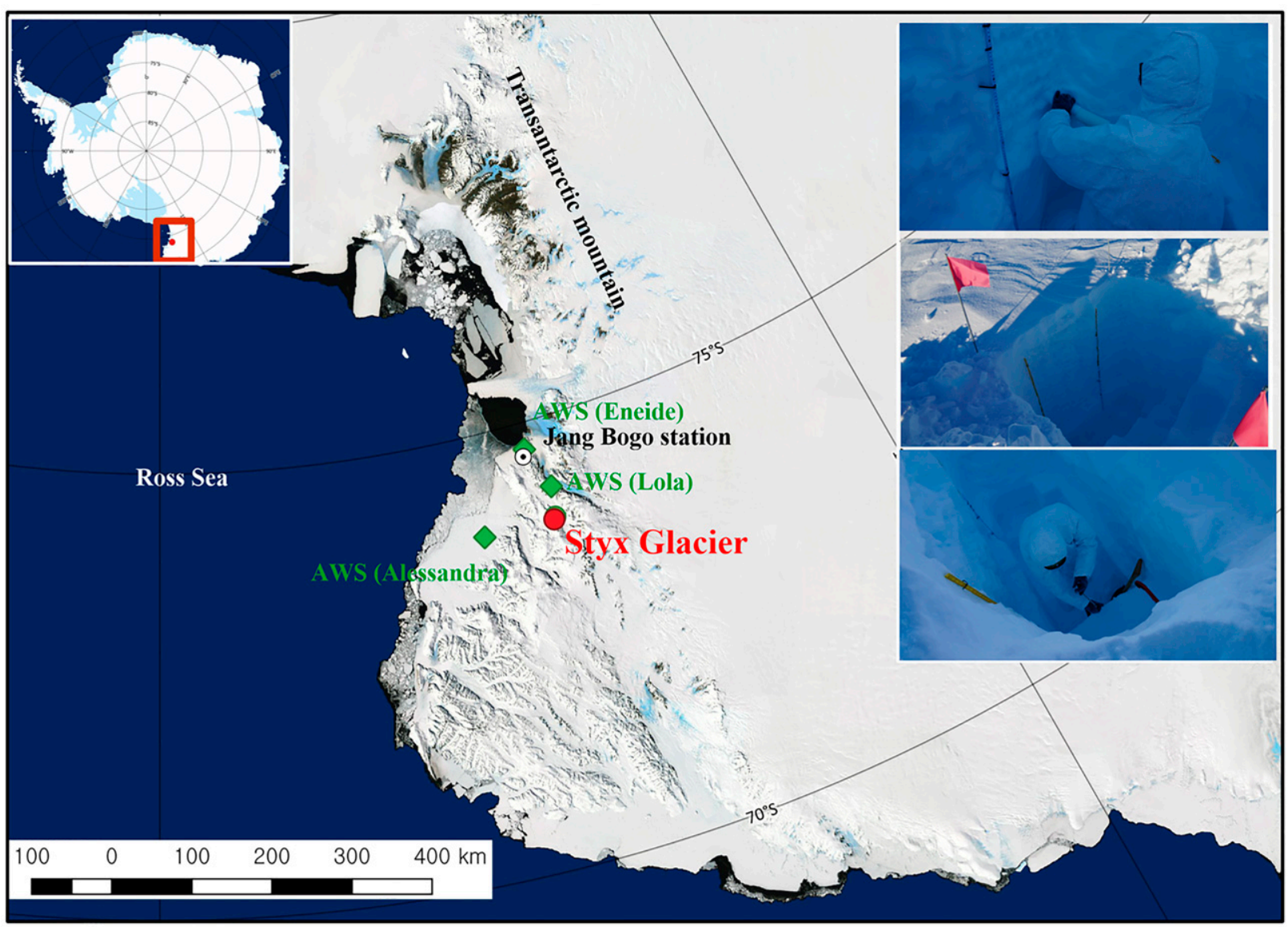

FIG. 1. Map of the snow-pit sampling site on Styx Glacier, the South Korean Jang Bogo Station, and three Italian automatic weather stations (Lola, Alessandra, and Eneide) in East Antarctica. The snow-sampling procedure is shown in the upper-right corner.

seasonality in potential and dominant climate factors, which alter the snow-pit record in this location. This work reports the most recent and high-resolution snow-pit record in the Styx Glacier. Our results will support the previous records reported (Udisti et al. 1998; Stenni et al. 2000; Traversi et al. 2004; Kwak et al. 2015) and further interpretation of long cores from this site.

\section{Data and methods}

\section{a. Site description}

The Styx Glacier $\left(73^{\circ} 50^{\prime} \mathrm{S}, 163^{\circ} 41^{\prime} \mathrm{E}\right.$; $\left.1623 \mathrm{~m} \mathrm{MSL}\right)$ in northern Victoria Land, East Antarctica, is located west of the Ross Sea coast and north of Jang Bogo Station on the South Korean Antarctic base (Fig. 1). The snow pit was retrieved in December 2014. At this latitude (annual mean temperature of $-32.5^{\circ} \mathrm{C}$ ) (Yang et al. 2018), the summer snowmelt, which typically makes it more difficult to distinguish seasonal snow layers, is less of a factor (Udisti et al. 1998; Lee 2014; Lee et al. 2020). The ablation, accumulation, and redistribution of the snow layers are relatively weak, and the western and northwestern katabatic winds are reduced by the Campbell Glacier valley (Udisti et al. 1999).
Cyclonically driven snow accumulation is common (Bertler et al. 2018), and southerly and southwesterly winds are dominant, accompanied by a low pressure center over the Ross Sea (Drewry et al. 1982; Udisti et al. 1999; Scarchilli et al. 2011; Sinclair et al. 2012). Annual mean accumulation rates of $203 \mathrm{~kg} \mathrm{~m}^{-2} \mathrm{yr}^{-1}$ (Stenni et al. 2000; 1974-90), $226 \mathrm{~kg} \mathrm{~m}^{-2} \mathrm{yr}^{-1}$ (Kwak et al. 2015; 2009-12), and $146 \pm 60 \mathrm{~kg} \mathrm{~m}^{-2} \mathrm{yr}^{-1}$ (Nyamgerel et al. 2020; 19902014) were estimated in the previous studies in the Styx Glacier. Thus, better seasonal signals in water isotopes and ions in snow layers assumed to be obtained with this relatively large accumulation (Frezzotti et al. 2007; lizuka et al. 2017). In addition, the combination of the high-altitude Transantarctic Mountains and the low coastal areas means that this site is a potential location for the study of airmass transport at both the regional and global scale (Udisti et al. 1998). Furthermore, because of its proximity to the Ross Sea, the site also has the potential to be used for investigations into temporal changes in the SIE (Drewry et al. 1982; Stenni et al. 2000; Han et al. 2015; Kwak et al. 2015).

\section{b. Sampling and measurements}

The wall of the pit was removed using precleaned low-density polyethylene (LDPE) shovels. Samples were obtained at intervals of $0.05 \mathrm{~m}$ with a precleaned polytetrafluoroethylene (PTFE) tube 
and a hammer and transferred into precleaned LDPE bottles. All of the sampling followed a procedure to prevent sample contamination (Kwak et al. 2015). The samples were shipped and stored frozen before isotopic and ionic analysis at KOPRI. The samples were melted at room temperature in a clean room, subsampled, and filtered using a $0.45-\mu \mathrm{m}$ polyvinylidene difluoride syringe filter (Merck Millipore, United States).

A total of 32 samples were decanted into 2-ml glass vials, and their isotopic composition was measured using cavity ring-down spectroscopy (Picarro, Inc., L1102-i, L2130-i, and L2140-i). Vienna Standard Mean Ocean Water (VSMOW), Greenland Ice Sheet Precipitation, and Standard Light Antarctic Precipitation from the International Atomic Energy Agency were used to calibrate the isotope analysis. An in-house reference prepared from Antarctic snowmelt was measured every 10 samples to monitor the operation of the analyzer. Isotopic ratios are expressed in delta notation $\left(\delta^{18} \mathrm{O}\right.$ and $\left.\delta \mathrm{D}\right)$ by the following equation with a unit of per mill $(\%)$ :

$$
\delta=\left(\frac{R_{\text {sample }}-R_{\text {VSMOW }}}{R_{\text {VSMOW }}}\right) \times 1000,
$$

where $R$ represents the ratio of heavy to light isotopes $\left({ }^{18} \mathrm{O} /{ }^{16} \mathrm{O}\right.$ and $\mathrm{D} /{ }^{1} \mathrm{H}$ ) in both the sample and the VSMOW. Analytical reproducibility was better than $0.1 \%$ and $1 \%$ for $\delta^{18} \mathrm{O}$ and $\delta \mathrm{D}$, respectively. The deuterium excess ( $d$-excess), which represents the deviation from global meteoric water line, was estimated using an equation that is based on Dansgaard (1964):

$$
d \text {-excess }=\delta \mathrm{D}-8 \times \delta^{18} \mathrm{O}
$$

Ions $\left(\mathrm{Na}^{+}, \mathrm{Mg}^{2+}, \mathrm{K}^{+}, \mathrm{Ca}^{2+}, \mathrm{Cl}^{-}, \mathrm{SO}_{4}^{2-}, \mathrm{MSA}\right.$, and $\left.\mathrm{NO}_{3}^{-}\right)$were analyzed using a two-channel ion chromatography system (Thermo Fisher Scientific, Inc., ICS-2000 and ICS-2100) at KOPRI. Anions were analyzed using Dionex model ICS-2000 with an IonPac AS15 column and $\mathrm{KOH}$ eluent (6-55 mM), and the cations were measured using Dionex model ICS-2100 with an IonPac CS12A column and MSA eluent (20 mM). The analytical detection limit, reproducibility, and accuracy were $0.01-0.26 \mu \mathrm{g} \mathrm{L}^{-1}, 0.4-17.4 \%$, and $4.5-12.0 \%$ for cations, respectively, and $0.02-0.26 \mu \mathrm{g} \mathrm{L}^{-1}, 0.1-27.6 \%$, and $1.3-5.6 \%$ for anions, respectively (Hong et al. 2012). Using the theoretical ratio of a specific ion to $\mathrm{Na}^{+}$in seawater (Pilson 2013), the nss fraction of the ions, including $\mathrm{Cl}^{-}, \mathrm{SO}_{4}^{2-}, \mathrm{K}^{+}, \mathrm{Mg}^{2+}$, and $\mathrm{Ca}^{2+}$, were estimated to isolate the contribution of sea spray by the following equation (Kuramoto et al. 2011):

$$
\operatorname{nss}[X]=\operatorname{tot}[X]-\left(\frac{X}{\mathrm{Na}^{+}}\right)_{\mathrm{sw}} \times \mathrm{Na}^{+},
$$

where $[X]$ is the target ion and $\left(X / \mathrm{Na}^{+}\right)_{\mathrm{sw}}$ is the ratio of that ion and $\mathrm{Na}^{+}$in seawater. Similarly, the massive representations of the ions $\left(\mathrm{Cl}^{-}, \mathrm{SO}_{4}^{2-}, \mathrm{K}^{+}, \mathrm{Mg}^{2+}\right.$, and $\left.\mathrm{Ca}^{2+}\right)$, the enrichment factors $(\mathrm{EF})$, were calculated by dividing the mass ratios of the $[X] / \mathrm{Na}^{+}$in the samples by those in seawater (Pilson 2013). Additionally, the $\mathrm{Sr}$ concentration analyzed by inductively coupled plasma sector field mass spectrometry with detection limit of $0.242 \mu \mathrm{g} \mathrm{L}^{-1}$ and accuracy of $2.8 \%$ (Thermo Fisher
Scientific) in KOPRI and its crustal enrichment factor (using $\mathrm{Al}$ as reference element) were compared.

The peak values of $\delta^{18} \mathrm{O}, \delta \mathrm{D}$, nssSO ${ }_{4}^{2-}$, MSA, and $\mathrm{NO}_{3}^{-}$in the austral summer period, which are related to the seasonality of their sources (Udisti 1996; Kwak et al. 2015; Caiazzo et al. 2016), were identified and used for snow-pit dating. We were able to assume the maximum of $\delta^{18} \mathrm{O}$ (or $\delta \mathrm{D}$ ) as a midsummer (1 January) and the minimum as a midwinter (July) with comparison of $\mathrm{nsSO}_{4}^{2-}, \mathrm{MSA}$, and $\mathrm{NO}_{3}^{-}$in the snow pit, which is similar to previous studies (Rhodes et al. 2012; Markle et al. 2012; Tuohy et al. 2015). The period between the peaks was determined using linear interpolation, and the number of measurements for each year ranged from 6 to 9. A density of $371 \mathrm{~kg} \mathrm{~m}^{-3}$, which was measured in upper layers in an ice core at same location (Han et al. 2015), was used to calculate snow accumulation rate in water equivalent.

Isotopic values $\left(\delta^{18} \mathrm{O}\right.$ and $\left.\delta \mathrm{D}\right)$ of the snow pit were compared with the precipitation isotopic composition (monthly mean) simulated by isotope-enabled atmospheric general circulation model (IsoGSM2) (Yoshimura et al. 2008). IsoGSM2 model has been introduced by the isotope fractionation process and spectrally nudged toward the meteorological conditions by National Centers for Environmental Prediction (NCEP) reanalysis (Yoshimura et al. 2008). The European Centre for Medium-Range Weather Forecasts interim reanalysis (ERAInterim) dataset provided the precipitation and temperature data (Dee et al. 2011). Two-meter temperature data were taken from the nearest automatic weather station (AWS) (Lola) and two other stations in the northwest and southwest of the study area (Alessandra and Eneide, respectively) (http:// www.climantartide.it) and compared with the snow-pit records. The location of the AWS Alessandra and Eneide are in the direction of the dominant wind path. The snow-pit records also were compared with the SIE time series for the Ross Sea region (Parkinson and Cavalieri 2012; data archive at the National Snow and Ice Data Center).

\section{Results and discussion}

The descriptive statistics and correlation matrix of water isotopes and ions are shown in Tables 1 and 2 . The positive correlations between $\delta^{18} \mathrm{O}, \delta \mathrm{D}, \mathrm{MSA}$, and $\mathrm{nssSO}_{4}^{2-}$ indicate their increase in warm period. The distribution of $\mathrm{NO}_{3}^{-}$show correlation to the $d$-excess $(r=-0.43 ; p=0.013)$ and $\mathrm{nssSO}_{4}^{2-}$ $(r=0.42 ; p=0.017)$. The double peaks of $d$-excess in 2014 and the inconsistent relationship between $\mathrm{NO}_{3}^{-}$and $\delta^{18} \mathrm{O}$ after winter 2013 are likely to indicate the occurrence of event-based changes (Fig. 2). For the ions, strong positive correlations $r$ were observed among the ions $\mathrm{Na}^{+}, \mathrm{K}^{+}, \mathrm{Mg}^{2+}, \mathrm{Ca}^{2+}, \mathrm{Cl}^{-}$, and totSO ${ }_{4}^{2-}(r>\sim 0.90$; Table 2$)$, and the slope of the linear relationship between $\mathrm{Na}^{+}$and the other ions was similar to their respective ratios in seawater (Table 3 ). This indicates a dominant contribution of deposition of sea-salt aerosols in the snow pit (Piccardi et al. 1994; Traversi et al. 2004). The large nss fractions of $\mathrm{SO}_{4}^{2-}(65.5 \%)$ and $\mathrm{Ca}^{2+}(64.9 \%)$ indicated other potential sources. The nss fractions of $\mathrm{Cl}^{-}(25.1 \%)$ and of $\mathrm{Mg}^{2+}$ averaged $25.5 \%(n=25)$, except for some negative values. For $\mathrm{K}^{+}$, the nss fraction was not able to be calculated 
TABLE 1. Statistics of the isotopes and ions from different studies in northern Victoria Land.

\begin{tabular}{|c|c|c|c|c|c|c|c|}
\hline & $\begin{array}{l}\text { Stenni et al. } \\
(2000)\end{array}$ & $\begin{array}{c}\text { Gragnani et al. } \\
\text { (1998) }\end{array}$ & $\begin{array}{l}\text { This } \\
\text { study }\end{array}$ & $\begin{array}{l}\text { Nyamgerel } \\
\text { et al. (2020) }\end{array}$ & $\begin{array}{l}\text { Stenni } \\
\text { et al. } \\
(2000)\end{array}$ & $\begin{array}{l}\text { Stenni } \\
\text { et al. } \\
(2000)\end{array}$ & $\begin{array}{c}\text { Severi } \\
\text { et al. } \\
(2009)\end{array}$ \\
\hline Time period & $1980-87$ & $1986-94$ & 2010-14 & 1990-2014 & 1971-90 & $1973-92$ & \\
\hline Type of record & Firn core & Firn core & Snow pit & Firn core & Firn core & Firn core & Ice core \\
\hline Accumulation rate $\left(\mathrm{kg} \mathrm{m}^{-2} \mathrm{yr}^{-1}\right)$ & $130-426$ & $140-180$ & 143.71 & 146 & $111-335$ & $83-265$ & 77.4 \\
\hline Altitude (m MSL) & 650 & 1560 & 1630 & 1630 & 1800 & 3000 & 2316 \\
\hline Distance from coast $(\mathrm{km})$ & 40 & $\sim 70$ & $\sim 60$ & $\sim 60$ & 50 & 75 & 250 \\
\hline Location & $\begin{array}{l}\text { McCarthy } \\
\text { Ridge }\end{array}$ & $\begin{array}{l}\text { Campbell } \\
\text { Glacier C }\end{array}$ & $\begin{array}{l}\text { Styx } \\
\text { Glacier }\end{array}$ & $\begin{array}{l}\text { Styx } \\
\text { Glacier }\end{array}$ & $\begin{array}{l}\text { Styx } \\
\text { Glacier }\end{array}$ & $\begin{array}{c}\text { Hercules } \\
\text { Neve }\end{array}$ & $\begin{array}{l}\text { Talos } \\
\text { Dome }\end{array}$ \\
\hline$\delta^{18} \mathrm{O}(\%)$ mean & -25.5 & -33.5 & -36.16 & -34.92 & -32.9 & -33.6 & - \\
\hline$\delta^{18} \mathrm{O}(\%) \mathrm{SD}$ & 4.4 & & 5.02 & 3.13 & 3.2 & 2.4 & - \\
\hline$\delta^{18} \mathrm{O}(\%) \max$ & -17.1 & -27.2 & -24.90 & -26.70 & -23.7 & -27.0 & - \\
\hline$\delta^{18} \mathrm{O}(\%) \mathrm{min}$ & -37 & -40.8 & -43.91 & -43.13 & -39.2 & -42.0 & - \\
\hline $\operatorname{MSA}\left(\mu \mathrm{g} \mathrm{L}^{-1}\right)$ mean & 26.7 & 16.17 & 14.12 & 8.12 & 13.6 & 94 & 5.36 \\
\hline $\operatorname{MSA}\left(\mu \mathrm{g} \mathrm{L}^{-1}\right) \mathrm{SD}$ & 24.4 & 12.36 & 15.78 & 7.17 & 10.1 & 6.9 & 6.61 \\
\hline $\operatorname{MSA}\left(\mu \mathrm{g} \mathrm{L}^{-1}\right) \max$ & 143.0 & 71.32 & 66.08 & 53.71 & 57.3 & 118.3 & 40.49 \\
\hline $\operatorname{MSA}\left(\mu \mathrm{g} \mathrm{L}^{-1}\right) \min$ & 2.0 & 3.80 & 2.03 & 1.34 & 2.5 & 12.7 & 0.42 \\
\hline $\mathrm{nssSO}_{4}^{2-}\left(\mu \mathrm{g} \mathrm{L}^{-1}\right)$ mean & 131.6 & 62.44 & 44.36 & 49.87 & 57.5 & 46.2 & 42 \\
\hline $\mathrm{nssSO}_{4}^{2-}\left(\mu \mathrm{g} \mathrm{L}^{-1}\right) \mathrm{SD}$ & 92.8 & 76.85 & 37.82 & 49.22 & 36.0 & 27.8 & 27.47 \\
\hline $\mathrm{nssSO}_{4}^{2-}\left(\mu \mathrm{g} \mathrm{L}^{-1}\right) \max$ & 405.9 & 408.27 & 163.28 & 523.03 & 270.4 & 178.6 & 100.2 \\
\hline $\mathrm{nssSO}_{4}^{2-}\left(\mu \mathrm{g} \mathrm{L}^{-1}\right) \min$ & 5.2 & -273.78 & 5.00 & 4.10 & 1.7 & 0.8 & 6.59 \\
\hline $\mathrm{Na}^{+}\left(\mu \mathrm{g} \mathrm{L}^{-1}\right)$ mean & - & 485.07 & 59.23 & 171.07 & - & - & 21.79 \\
\hline $\mathrm{Na}^{+}\left(\mu \mathrm{g} \mathrm{L}^{-1}\right) \mathrm{SD}$ & - & 625.30 & 1480.14 & 671.04 & - & - & 16.14 \\
\hline $\mathrm{Na}^{+}\left(\mu \mathrm{g} \mathrm{L}^{-1}\right) \max$ & - & 4620.79 & 6706.94 & 8802.32 & - & - & 84.87 \\
\hline $\mathrm{Na}^{+}\left(\mu \mathrm{g} \mathrm{L}^{-1}\right) \min$ & - & 20.69 & 1.16 & 1.20 & - & - & 2.52 \\
\hline $\mathrm{Ca}^{2+}\left(\mu \mathrm{g} \mathrm{L}^{-1}\right)$ mean & - & 82.16 & 24.56 & 26.97 & - & - & 2.80 \\
\hline $\mathrm{Ca}^{2+}\left(\mu \mathrm{g} \mathrm{L}^{-1}\right) \mathrm{SD}$ & - & 54.11 & 52.04 & 51.08 & - & - & 1.88 \\
\hline $\mathrm{Ca}^{2+}\left(\mu \mathrm{g} \mathrm{L}^{-1}\right) \max$ & - & 402.78 & 236.13 & 362.57 & - & - & 20.71 \\
\hline $\mathrm{Ca}^{2+}\left(\mu \mathrm{g} \mathrm{L}^{-1}\right) \min$ & - & 18.04 & 2.77 & 2.73 & - & - & 0.76 \\
\hline $\mathrm{K}^{+}\left(\mu \mathrm{g} \mathrm{L}^{-1}\right)$ mean & - & 144.66 & 20.47 & 7.38 & - & - & - \\
\hline $\mathrm{K}^{+}\left(\mu \mathrm{g} \mathrm{L}^{-1}\right) \mathrm{SD}$ & - & 191.58 & 57.15 & 28.60 & - & - & - \\
\hline $\mathrm{K}^{+}\left(\mu \mathrm{g} \mathrm{L}^{-1}\right) \max$ & - & 1266.78 & 275.63 & 373.13 & - & - & - \\
\hline $\mathrm{K}^{+}\left(\mu \mathrm{g} \mathrm{L}^{-1}\right) \min$ & - & 19.55 & 0.84 & 0.43 & - & - & - \\
\hline $\mathrm{Mg}^{2+}\left(\mu \mathrm{g} \mathrm{L}^{-1}\right)$ mean & - & 44.96 & 61.58 & 20.86 & - & - & 2.31 \\
\hline $\mathrm{Mg}^{2+}\left(\mu \mathrm{g} \mathrm{L}^{-1}\right) \mathrm{SD}$ & - & 60.76 & 165.31 & 77.67 & - & - & 1.63 \\
\hline $\mathrm{Mg}^{2+}\left(\mu \mathrm{g} \mathrm{L}^{-1}\right) \max$ & - & 466.66 & 768.47 & 1042.42 & - & - & 10.56 \\
\hline $\mathrm{Mg}^{2+}\left(\mu \mathrm{g} \mathrm{L}^{-1}\right) \min$ & - & 8.51 & 1.49 & 1.07 & - & - & 0.36 \\
\hline $\mathrm{Cl}^{-}\left(\mu \mathrm{g} \mathrm{L}^{-1}\right)$ mean & - & 808.33 & 1018.27 & 339.42 & - & - & 46.73 \\
\hline $\mathrm{Cl}^{-}\left(\mu \mathrm{g} \mathrm{L}^{-1}\right) \mathrm{SD}$ & - & 1052.95 & 2672.45 & 1239.98 & - & - & 30.72 \\
\hline $\mathrm{Cl}^{-}\left(\mu \mathrm{g} \mathrm{L}^{-1}\right) \max$ & - & 6877.88 & 12205.73 & 16394.61 & - & - & 184.1 \\
\hline $\mathrm{Cl}^{-}\left(\mu \mathrm{g} \mathrm{L}^{-1}\right) \min$ & - & 88.63 & 7.30 & 6.58 & - & - & 6.54 \\
\hline $\mathrm{SO}_{4}^{2-}\left(\mu \mathrm{g} \mathrm{L}^{-1}\right)$ mean & - & 182.52 & 178.20 & 91.63 & - & - & 47.52 \\
\hline $\mathrm{SO}_{4}^{2-}\left(\mu \mathrm{g} \mathrm{L}^{-1}\right) \mathrm{SD}$ & - & 158.50 & 373.67 & 188.53 & - & - & 27.47 \\
\hline $\mathrm{SO}_{4}^{2-}\left(\mu \mathrm{g} \mathrm{L}^{-1}\right) \max$ & - & 979.84 & 1732.80 & 2506.58 & - & - & 139.6 \\
\hline $\mathrm{SO}_{4}^{2-}\left(\mu \mathrm{g} \mathrm{L}^{-1}\right) \min$ & - & 43.23 & 14.08 & 13.38 & - & - & 12.42 \\
\hline $\mathrm{NO}_{3}^{-}\left(\mu \mathrm{g} \mathrm{L}^{-1}\right)$ mean & - & 60.14 & 49.28 & 42.46 & - & - & 47.38 \\
\hline $\mathrm{NO}_{3}^{-}\left(\mu \mathrm{g} \mathrm{L}^{-1}\right) \mathrm{SD}$ & - & 26.04 & 24.42 & 19.15 & - & - & 13.49 \\
\hline $\mathrm{NO}_{3}^{-}\left(\mu \mathrm{g} \mathrm{L}^{-1}\right) \max$ & - & 189.73 & 130.7 & 118.91 & - & - & 100.2 \\
\hline $\mathrm{NO}_{3}^{-}\left(\mu \mathrm{g} \mathrm{L}^{-1}\right) \min$ & - & 12.40 & 12.68 & 10.09 & - & - & 21.59 \\
\hline
\end{tabular}


TABLE 2. Correlation matrix for the isotopic and ionic species in the snow pit. Correlation coefficient values larger than 0.4 are highlighted in boldface type $(n=32)$.

\begin{tabular}{|c|c|c|c|c|c|c|c|c|c|c|c|c|}
\hline & $\delta^{18} \mathrm{O}$ & $\delta \mathrm{D}$ & $d$-excess & MSA & $\mathrm{Cl}^{-}$ & $\mathrm{nssSO}_{4}^{2-}$ & totSO ${ }_{4}^{2-}$ & $\mathrm{NO}_{3}^{-}$ & $\mathrm{Na}^{+}$ & $\mathrm{K}^{+}$ & $\mathrm{Mg}^{2+}$ & $\mathrm{Ca}^{2+}$ \\
\hline$\overline{\delta^{18} \mathrm{O}}$ & 1.00 & & & & & & & & & & & \\
\hline$\delta \mathrm{D}$ & 1.00 & 1.00 & & & & & & & & & & \\
\hline$d$-excess & -0.19 & -0.11 & 1.00 & & & & & & & & & \\
\hline MSA & 0.41 & 0.45 & 0.35 & 1.00 & & & & & & & & \\
\hline $\mathrm{Cl}^{-}$ & 0.11 & 0.12 & 0.02 & -0.15 & 1.00 & & & & & & & \\
\hline $\mathrm{nssSO}_{4}^{2-}$ & 0.56 & 0.57 & 0.02 & 0.63 & 0.05 & 1.00 & & & & & & \\
\hline totSO $\mathrm{S}_{4}^{2-}$ & 0.17 & 0.18 & 0.02 & -0.08 & 0.99 & 0.15 & 1.00 & & & & & \\
\hline $\mathrm{NO}_{3}^{-}$ & 0.31 & 0.28 & -0.43 & -0.02 & 0.03 & 0.42 & 0.07 & 1.00 & & & & \\
\hline $\mathrm{Na}^{+}$ & 0.12 & 0.12 & 0.02 & -0.14 & 1.00 & 0.04 & 0.99 & 0.03 & 1.00 & & & \\
\hline $\mathrm{K}^{+}$ & 0.35 & 0.12 & 0.02 & -0.14 & 1.00 & 0.05 & 1.00 & 0.03 & 1.00 & 1.00 & & \\
\hline $\mathrm{Mg}^{2+}$ & 0.11 & 0.12 & 0.03 & -0.14 & 1.00 & 0.06 & 1.00 & 0.02 & 1.00 & 1.00 & 1.00 & \\
\hline $\mathrm{Ca}^{2+}$ & 0.14 & 0.15 & 0.00 & -0.14 & 0.99 & 0.11 & 0.99 & 0.07 & 0.99 & 0.99 & 0.99 & 1.00 \\
\hline
\end{tabular}

because of the negative values $(n=18)$. These negative values for $\mathrm{K}^{+}$and $\mathrm{Mg}^{2+}$ are indicative of the fractionation of these ions when $\mathrm{Na}^{+}$is considered as solely originating from seawater. Table 1 compares the mean values of isotopes and ionic species recorded in northern Victoria Land. Depending on the site location (altitude and distance to coast), distinct values were reported; however, Styx snow-pit records were in similar range to the records except for McCarthy Ridge $(40 \mathrm{~km}$ to coast) and Talos Dome sites (250 km to coast). Temporally, there was no significant difference $(p>0.05)$ in the isotopic and chemical compositions of the snow pit when compared with the firn core record in the same period (Nyamgerel et al. 2020).

The $\delta^{18} \mathrm{O}, \delta \mathrm{D}, \mathrm{nssSO}_{4}^{2-}, \mathrm{MSA}$, and $\mathrm{NO}_{3}^{-}$in the snow pit indicate the snow layers deposited in the warm period (spring and summer) and used for snow-pit dating. The snow pit covered the period between January 2011 and January 2015 (4 full years) with an average snow depth of $0.39 \pm 0.05 \mathrm{~m}(n=4)$, corresponding to an annual accumulation of $143.71 \pm 17.75 \mathrm{~kg} \mathrm{~m}^{-2} \mathrm{yr}^{-1}$. We note that the dating uncertainty is on a monthly scale since we based it on the increased summer and decreased winter values of $\delta^{18} \mathrm{O}, \delta \mathrm{D}$, $\mathrm{nssSO}_{4}^{2-}, \mathrm{MSA}$, and $\mathrm{NO}_{3}^{-}$.

\section{a. Seasonal variation of isotopes}

The $\delta^{18} \mathrm{O}, \delta \mathrm{D}$, and $d$-excess of the snow pit display wellpreserved seasonal cycles (Fig. 2). The $\delta^{18} \mathrm{O}$ values of the snow pit $(n=32)$ fluctuated between $-43.91 \%$ and $-24.90 \%$, whereas the $\delta \mathrm{D}$ values fluctuated between $-346.8 \%$ and $-194.1 \%(n=32)$. The $\delta^{18} \mathrm{O}$ values are in a similar range as the previous records in northern Victoria Land (Table 1) (Gragnani et al. 1998; Stenni et al. 1999, 2000; Kwak et al. 2015; Nyamgerel et al. 2020). The mean $\delta^{18} \mathrm{O}$ was slightly depleted in the snow pit $(-36.16 \% \pm$ $5.02 \%$ ) relative to the previous records in the firn cores, having mean values of $-32.9 \% \pm 3.2 \%$ (Stenni et al. 2000) and $-34.92 \% \pm 3.13 \%$ (Nyamgerel et al. 2020), and the mean value $(-35.77 \% \pm 4.55 \%)$ covering the same period obtained from upper part of the firn core (Nyamgerel et al. 2020). The sinusoidal trends in $\delta^{18} \mathrm{O}$ and $\delta \mathrm{D}$ are primarily representing their conventional correlation to annual temperature cycle (Dansgaard 1964; Petit et al. 1999). The peak values of $\delta^{18} \mathrm{O}$ (assumed to be in January) and the lowest values (assumed to be in July) ranged from $-33.96 \%$ to $-26.23 \%$ (standard deviation $1 \sigma$ is $3.17 \%$ ) and from $-43.91 \%$ to $-40.18 \%$ oo $(1 \sigma$ is $1.69 \%$ ), respectively. The variations in the summer $\delta^{18} \mathrm{O}$ values were more pronounced than those in the winter, likely because of precipitation amounts and postdepositional processes (Casado et al. 2018).

A linear relationship between $\delta^{18} \mathrm{O}$ and $\delta \mathrm{D}$ was examined, with a slope of $7.87\left(\delta D=7.87 \delta^{18} \mathrm{O}+0.99, R^{2}=0.99, n=32\right.$, and $p<0.001$ ), which is similar to the precipitation isotopic composition of both the global scale (slope of 8.00) (Dansgaard 1964) and the whole Antarctic scale (slope of 7.75) (MassonDelmotte et al. 2008). This may reflect the minimal effects of sublimation process and melting processes (Lee et al. 2010; Steen-Larsen et al. 2014). The mean $d$-excess was $5.59 \%$, with a maximum of $11.48 \%$ and a minimum of $0.96 \%(n=25)$. The annual cycle in $d$-excess was similar in 2011 and 2012, with the maximum values during May and June and a sharp minimum in November; whereas in 2013 and 2014, the maximum values were detected earlier. The $d$-excess could be influenced by the sublimation of surface snow and changes in precipitation seasonality (Steen-Larsen et al. 2014; Casado et al. 2018) and the changes in relative humidity, sea surface temperature, and wind speeds in the airmass source area (Merlivat and Jouzel 1979).

\section{b. Seasonal variation of ions}

The variations of ions are presented in Fig. 2. MSA and $\mathrm{nssSO}_{4}^{2-}$ are the oxidation products of dimethylsulphide (DMS) from marine algae and phytoplankton during austral spring and summer (Udisti et al. 1998). Although $\mathrm{nssSO}_{4}^{2-}$ in polar ice cores can be derived from crustal erosion and volcanic emissions (Handler 1989; Delmas et al. 1992; Legrand and Mayewski 1997; Cole-Dai et al. 1999), the emission from marine activity is large, especially in coastal sites (Dixon et al. 2004; Jonsell et al. 2005; Uemura et al. 2016). MSA and $\mathrm{nsSSO}_{4}^{2-}$ in the snow pit show increased values during the summer period relating to the strong seasonality of DMS production. This seasonal pattern is in line with the other studies (Legrand et al. 1992; Udisti et al. 1998; Saltzman et al. 2006; Rhodes et al. 2012; Becagli et al. 2016). The negative value for $\mathrm{nsSO}_{4}^{2-}$ was detected at a depth of $0.025 \mathrm{~m}$, which commonly indicate the winter sea-spray aerosol (relative depletion of $\mathrm{SO}_{4}^{2--}$ by precipitation of mirabilite $\mathrm{Na}_{2} \mathrm{SO}_{4}$ ) 


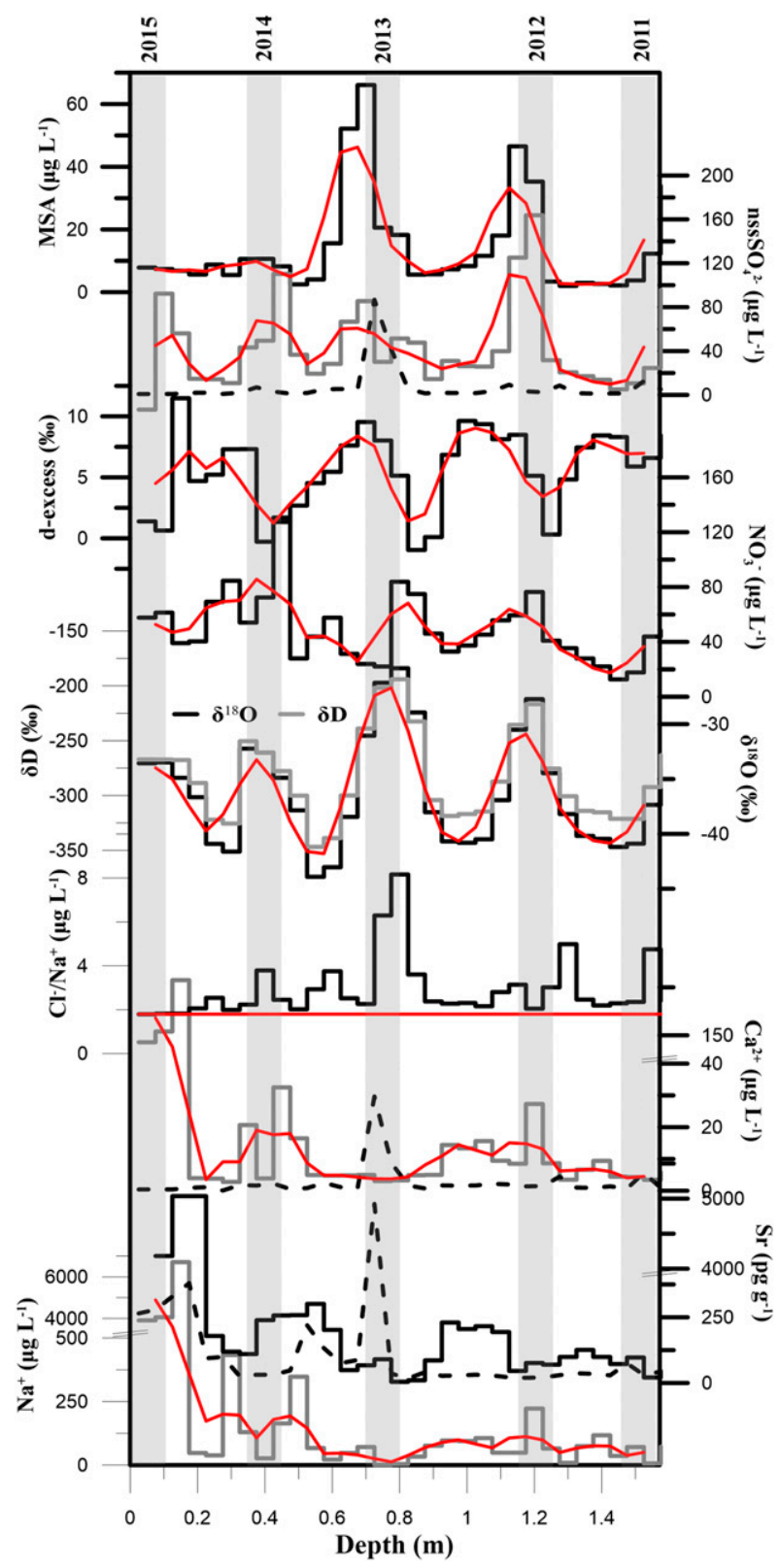

FIG. 2. Profiles of concentration vs depth for isotopic composition and ionic species with three-point running average (red lines). The $\mathrm{Cl}^{-} / \mathrm{Na}^{+}$ratio is shown with its typical seawater ratio of 1.794 (red line). The shaded areas represent the summer peaks from January 2011 to January 2015. Black dashed lines are the sea-salt $\mathrm{EF}$ for $\mathrm{SO}_{4}^{2-}$ and $\mathrm{Ca}^{2+}$ and crustal $\mathrm{EF}$ for $\mathrm{Sr}$ and highlight their sharp increases in January 2013.

(Piccardi et al. 1996; Udisti et al. 1998; Benassai et al. 2005). In the snow pit, this value is likely to indicate the occasional large concentration of $\mathrm{Na}^{+}$relative to $\mathrm{SO}_{4}^{2-}$ in this depth (as well as depth to $0.125 \mathrm{~m})$. The MSA peaks in $2013\left(66.08 \mu \mathrm{g} \mathrm{L}^{-1}\right)$ and $2012\left(46.51 \mu \mathrm{g} \mathrm{L}^{-1}\right)$ were larger than those in the other years, whereas the $\mathrm{nssSO}_{4}^{2-}$ exhibited relatively consistent peaks. There can be differences in the transport pathways of MSA and
TABLE 3. Linear regression of $\mathrm{Na}^{+}$vs $\mathrm{K}^{+}, \mathrm{Mg}^{2+}, \mathrm{Ca}^{2+}$, and $\mathrm{Cl}^{-}$ with a comparison with their theoretical ratios in seawater (Pilson 2013).

\begin{tabular}{lcccrl}
\hline \hline & $\mathrm{Cl}^{-}$ & $\mathrm{ssSO}_{4}^{2-}$ & $\mathrm{Mg}^{2+}$ & $\mathrm{K}^{+}$ & $\mathrm{Ca}^{2+}$ \\
\hline Seawater ratio & 1.794 & 0.252 & 0.119 & 0.037 & 0.038 \\
Slope & 1.805 & 0.251 & 0.112 & 0.038 & 0.035 \\
Intercept & 44.734 & 42.87 & 1.444 & -0.346 & 5.75 \\
$R^{2}$ & 0.999 & 0.989 & 0.997 & 0.999 & 0.983 \\
$n$ & 32 & 32 & 32 & 32 & 32 \\
$p$ & $<0.001$ & $<0.001$ & $<0.001$ & $<0.001$ & $<0.001$ \\
\hline
\end{tabular}

nssSO $_{4}^{2-}$ (Becagli et al. 2012) and different rates of photochemical oxidation (Preunkert et al. 2008).

The $\mathrm{NO}_{3}^{-}$concentrations in polar precipitation are assumed to be increased in spring and summer period linked to the result of the sedimentation of polar stratospheric clouds and photo-induced atmospheric processes (Legrand and Delmas 1986; Mulvaney and Wolff 1993; Wagenbach et al. 1998; Traversi et al. 2004). The $\mathrm{NO}_{3}^{-}$concentrations (mean $49.28 \pm$ $24.42 \mu \mathrm{g} \mathrm{L}^{-1}$ ) in the snow pit generally increased in the late spring and summer period with secondary peaks at 2013 (May) and 2014 (April) (Fig. 2). There could be $\mathrm{NO}_{3}^{-}$loss by postdepositional and photochemical mechanisms (Legrand and

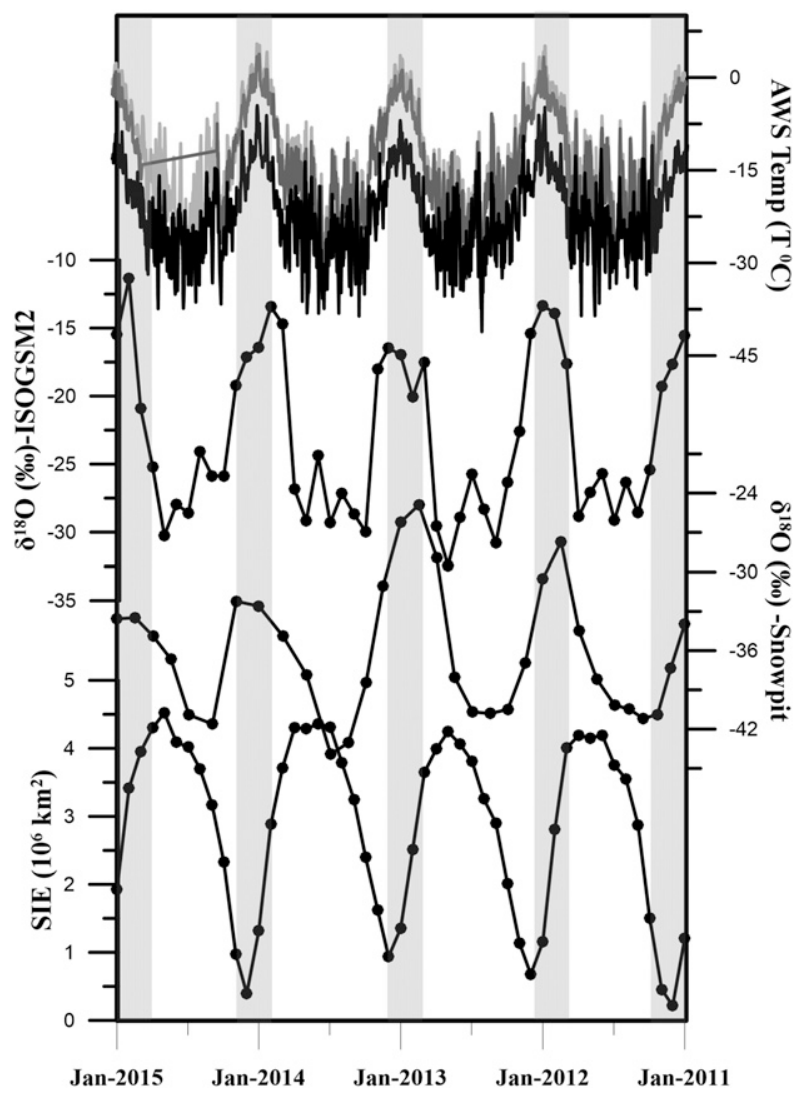

FIG. 3. Comparison of monthly mean SIE in the Ross Sea, $\delta^{18} \mathrm{O}$ of the snow pit and IsoGSM2 simulation, and daily temperature from Lola (black), Alessandra (dark gray), and Eneide (light gray). 
TABLE 4. Annual mean values of $\delta^{18} \mathrm{O}$, temperatures (labeled temp) from AWS (Lola, Eneide, and Alessandra) and ERA-Interim reanalysis data, SIE, and snow accumulation rate (labeled SA) from the snow pit and ERA-Interim reanalysis data (the largest values are highlighted in boldface type).

\begin{tabular}{ccccccccc}
\hline \hline Year & $\delta^{18} \mathrm{O}$ & Temp (Lola) & Temp (Eneide) & Temp (Alessandra) & Temp (ERA) & SA (ERA) & SA $($ snow pit) & SIE $\left(10^{6} \mathrm{~km}^{2}\right)$ \\
\hline 2014 & -36.05 & -22.30 & -13.32 & -13.62 & -15.16 & -29.07 & 137.88 & 129.85 \\
2013 & -36.49 & -22.62 & -13.60 & -15.33 & -28.96 & 159.84 & 129.85 \\
2012 & $-\mathbf{3 5 . 1 6}$ & -22.54 & -14.04 & $-\mathbf{2 7 . 1 4}$ & $\mathbf{2 0 3 . 7 4}$ & $\mathbf{1 6 6 . 9 5}$ \\
2011 & -37.16 & $-\mathbf{2 1 . 4 4}$ & $\mathbf{- 1 2 . 4 8}$ & -101 & 2.78 \\
\hline
\end{tabular}

Delmas 1988; Dibb and Whitlow 1996; Mulvaney et al. 1998; Röthlisberger et al. 2002), and still the nitrogen cycling is uncertain in Antarctica (Pasteris et al. 2014). However, a similar pattern has been observed in other studies (e.g., Pasteris et al. 2014; Kwak et al. 2015; Caiazzo et al. 2017), and we state that $\mathrm{NO}_{3}^{-}$can be used as an additional seasonal marker for age determination of ice core.

Sea salts show a high concentration in winter due to the intensive storms, which move the fragile sea-salt crystals formed above the sea ice surface (Brimblecombe 1996; Udisti et al. 1998; Rankin et al. 2000; Abram et al. 2007). Wind speeds larger than $9.7 \mathrm{~m} \mathrm{~s}^{-1}$ (mean velocity) were mostly observed in winter months ( $28.3 \%$ of total count) based on Lola AWS data. However, the concentrations of $\mathrm{Na}^{+}, \mathrm{K}^{+}, \mathrm{Mg}^{2+}, \mathrm{Ca}^{2+}, \mathrm{Cl}^{-}$, and totSO ${ }_{4}^{2-}$ in the snow pit show no consistent seasonality. A sharp increase of $\mathrm{Na}^{+}$as well as other sea-salt species was observed at a depth range of $0.025-0.125$ (Fig. 2). These are likely to indicate the dry deposition of large particles from seasalt aerosol during sea storms (Tuohy et al. 2015). The ratios of $\mathrm{Cl}^{-} / \mathrm{Na}^{+}$show mostly large values in the warm period. The intercept of $\mathrm{Cl}^{-}$and $\mathrm{Na}^{+}$indicates the presence of an extra source of $\mathrm{HCl}$. This could be related to the gaseous $\mathrm{HCl}$ as a consequence of exchange between $\mathrm{NaCl}$ and $\mathrm{HNO}_{3}$ or $\mathrm{H}_{2} \mathrm{SO}_{4}$ in the atmosphere (Legrand and Delmas 1988).

The average nss fraction of $\mathrm{Ca}^{2+}$ was $64.9 \%$, indicating the greater contribution of continental mineral dust than sea spray. A local ice-free area chained to the Transantarctic Mountains and long-range transport from South America are considered potential sources (Kreutz and Mayewski 1999). An enhancement of $\mathrm{nssCa}^{2+}$ in spring was observed in the other studies relating to wind-induced transport of crustal dust due to cyclonic activity (Rhodes et al. 2012; Caiazzo et al. 2017). However, the seasonal pattern of the concentration of $\mathrm{Ca}^{2+}$ was not as clear; it was high in the summer layers at depths of $0.325,0.425$, and $1.175 \mathrm{~m}$ but was low and stable at a depth of $0.525-0.875 \mathrm{~m}$. The EFs for $\mathrm{Ca}^{2+}$ as well as $\mathrm{nsSO}_{4}^{2-}$ show elevated values at a depth of $0.725 \mathrm{~m}$ as well as $\mathrm{Cl}^{-} / \mathrm{Na}^{+}$ratio at a depth of 0.725 and $0.775 \mathrm{~m}$ (Fig. 2).

\section{c. Comparison with meteorological records}

The monthly mean $\delta^{18} \mathrm{O}$ of the snow pit and simulation from IsoGSM2, SIE, and daily mean air temperature from three automatic weather stations are presented in Fig. 3. The mean values of $\delta^{18} \mathrm{O}$ and $\delta \mathrm{D}$ from IsoGSM2 show the enriched value by $13.11 \%$ and $109.15 \%$, respectively, relative to the mean value of that of the snow pit. Moreover, the variations in the snow-pit values were relatively large. This difference can be observed by the processes after snow deposition (e.g., wind erosion and sublimation), which is difficult to be captured in the IsoGSM2 simulation (Casado et al. 2018). On a seasonal scale, there was a positive correlation between the isotopic compositions of the snow pit and temperature from the nearest AWS Lola (south from the site), with a slope of $0.52 \%{ }^{\circ} \mathrm{C}^{-1}$ and a correlation coefficient of $0.59(n=32 ; p<0.001)$. For other two AWS (Eneide and Alessandra) slopes were decreased to $0.39 \%$ o ${ }^{\circ} \mathrm{C}^{-1}$. A correlation coefficient of $0.63(n=32 ; p<$ 0.001 ) was observed with temperature from Eneide (southwest from the site), whereas there is no correlation with Alessandra (northwest from the site). Since the southerly and southwesterly winds are predominant relating to the low pressure center over the Ross Sea (Scarchilli et al. 2011; Sinclair et al. 2012), the AWS observations (Lola and Eneide) in these directions are likely to show this trend. Based on Lola AWS observation during the period from 2011 to 2014, the prevailing winds are directed from the southwest (35.9\% of total counts) and west (17.1\% of total counts). From this point of view, the isotopic values appear to be relatively well preserved throughout the snow pit. Spatially and temporally different slopes were observed in the other studies, including $0.44 \%{ }^{\circ} \mathrm{C}^{-1}$ (van Ommen and Morgan 1997), $0.60 \%{ }^{\circ} \mathrm{C}^{-1}$ (Stenni et al. 2002), and $0.81 \%$ o ${ }^{\circ} \mathrm{C}^{-1}$ (Stenni et al. 2000). The difference in the isotope-temperature slope of snow pit $\left(0.52 \%{ }^{\circ} \mathrm{C}^{-1}\right.$ with temperature from AWS Lola) can result from various factors, including changes in evaporation conditions, transport pathway, and changes in precipitation seasonality (Werner et al. 2018) and postdepositional processes (Sinclair et al. 2010; Rhodes et al. 2012).

Goursaud et al. (2019) highlighted that the variability in precipitation dominantly influenced by the large-scale circulation particularly in coastal sites rather than the thermodynamic processes. Moreover, the potential impacts of southern annular mode (SAM) on Antarctic temperature (Marshall and Thompson 2016), precipitation (Marshall et al. 2017) and sea ice (Doddridge and Marshall 2017) have been reported recently. Thus, there has been increase in SIE particularly in Ross Sea region (Sinclair et al. 2014) with the cooling of the air temperature relating to the recent changes of SAM (Stenni et al. 2017; Yang et al. 2018). Annual mean of snow accumulation and $\delta^{18} \mathrm{O}\left(\delta^{18} \mathrm{O}\right.$ preferred, and the correlation to $\delta \mathrm{D}$ is 0.99 ) were shown together with the annual means of temperature (AWS and ERA-Interim reanalysis), SIE, and snow accumulation rate from ERA-Interim reanalysis (Table 4). The mean accumulation rate $\left(143.71 \pm 17.75 \mathrm{~kg} \mathrm{~m}^{-2} \mathrm{yr}^{-1}\right)$ during the 2011-14 period is comparable to the ERA-Interim reanalysis data $\left(165.90 \pm 27.49 \mathrm{~kg} \mathrm{~m}^{-2} \mathrm{yr}^{-1} ; n=4\right)$ and the firn core record (146 \pm $60 \mathrm{~kg} \mathrm{~m}^{-2} \mathrm{yr}^{-1} ; n=25$ ) (Nyamgerel et al. 2020). Moreover, this estimate is slightly lower than had been reported by previous 
studies (before 2011), ranging from 160 to $226 \mathrm{~kg} \mathrm{~m}^{-2} \mathrm{yr}^{-1}$ in northern Victoria Land (Udisti 1996; Stenni et al. 2000; Kwak et al. 2015). In other coastal Antarctic sites, the mean accumulation rates were $218 \mathrm{~kg} \mathrm{~m}^{-2} \mathrm{yr}^{-1}$ (Goursaud et al. 2017), $230 \mathrm{~kg} \mathrm{~m}^{-2} \mathrm{yr}^{-1}$ (Rhodes et al. 2012), $256 \mathrm{~kg} \mathrm{~m}^{-2} \mathrm{yr}^{-1}$ (Agosta et al. 2012), and $280 \mathrm{~kg} \mathrm{~m}^{-2} \mathrm{yr}^{-1}$ (Rahaman et al. 2016). In Talos Dome site $(\sim 250 \mathrm{~km}$ to coast), the accumulation rate was reported as $77.4 \mathrm{~kg} \mathrm{~m}^{-2} \mathrm{yr}^{-1}$ (Severi et al. 2009), which is $53.8 \%$ lower than the Styx snow pit. The differences in accumulation rate can be due to various event-based processes, including wind-driven snow distortion and snowdrifts, particularly in coastal sites (Frezzotti et al. 2004; Karlöf et al. 2005; Broeke 2008; Sinclair et al. 2010; Rhodes et al. 2012; Casado et al. 2018; Jang et al. 2019), and changes in evaporation conditions, transport pathways, and precipitation seasonality (Fujita and Abe 2006; Werner et al. 2018). The snow accumulation rates from the snow pit $\left(129.85 \mathrm{~kg} \mathrm{~m}^{-2} \mathrm{yr}^{-1}\right)$ and ERA-Interim reanalysis $\left(137.88 \mathrm{~kg} \mathrm{~m}^{-2} \mathrm{yr}^{-1}\right)$ in 2014 were lower by a factor of 1.3 (snow pit: $166.95 \mathrm{~kg} \mathrm{~m}^{-2} \mathrm{yr}^{-1}$ ) and 1.5 (ERA: $203.74 \mathrm{~kg} \mathrm{~m}^{-2} \mathrm{yr}^{-1}$ ) than those in 2011 . A linear correlation coefficient between snow accumulation from the snow pit and ERAInterim analysis was $0.91(n=4 ; p=0.08)$. By considering the vicinity to ocean and recent advance of SIE in the Ross Sea region (Severi et al. 2009), we suspect the potential influence of sea ice. The SIE in 2014 was 1.1 times larger than the SIE in 2011 in the Ross Sea region, which could reduce the intrusion of moist air mass to the deposition area (Table 4). The annual variations of SIE were inconsistent with the $\delta^{18} \mathrm{O}$ of the snow pit. It also can be seen that the annual mean temperatures (except Alessandra AWS) were lower in 2014 than the values in 2011. These results appear to state the accumulating snow is relatively consistent by preserving the noticeable climate and environmental conditions (e.g., changes in SIE or sea surface temperature).

The lower MSA peaks in 2013 and 2014 after the significantly large two peaks in 2012 and 2011 may likely to evidences the reduced emission of DMS due to the larger extent of sea ice (Abram et al. 2007) if we assume that changes in SIE are most significant in this region. The summer in 2012/13 where the largest peaks of $\delta^{18} \mathrm{O}, \delta \mathrm{D}$, and MSA, EF values of $\mathrm{SO}_{4}^{2-}$ and $\mathrm{Ca}^{2+}$, with large ratio of $\mathrm{Cl}^{-} / \mathrm{Na}^{+}$detected at $0.725 \mathrm{~m}$ (January 2013). This is likely to represent the occasional snow deposition with lower fraction of sea-salt ions. In addition, $\mathrm{Sr}$ concentration was low, but the crustal EF of Sr was peaked at this depth (Fig. 2). It may somehow under the influence of changes in strength and pathway of storm. We assume that it may be linked to the weakening of the westerly wind flowing to deposition area. This weakening could have related to the large negative values of SAM; thus, it could restrict the transport of sea salts. We observed a decreasing value of the SAM index from December 2012, and it reached in May 2013 the lowest value within the period from 2011 to 2014 (Marshall et al. 2018). There was also a different pattern at the depth ranges $0.025-0.2 \mathrm{~m}$ and $0.55-0.6 \mathrm{~m}$ showing relatively high values of $\mathrm{EF}$ for $\mathrm{Sr}$ but not for $\mathrm{SO}_{4}^{2-}$ and $\mathrm{Ca}^{2+}$. Although it is difficult to verify, these discrepancies can result from depositional (e.g., changes in airmass source) and postdepositional (e.g., wind erosion, sublimation) processes. Noise can be caused by nonclimatic processes; thus, the interpretation can be improved by use of ensemble records. Despite the fact that there is lack of robustness relating to the shortness of the record, we believe this work will allow comparisons with and is supportive to the further interpretation of deeper ice cores in this location.

\section{Conclusions}

This study discussed the isotopic $\left(\delta^{18} \mathrm{O}\right.$ and $\left.\delta \mathrm{D}\right)$ and chemical composition $\mathrm{Na}^{+}, \mathrm{Mg}^{2+}, \mathrm{K}^{+}, \mathrm{Ca}^{2+}, \mathrm{Cl}^{-}, \mathrm{SO}_{4}^{2-}, \mathrm{MSA}$, and $\mathrm{NO}_{3}^{-}$) in the snow pit from an Antarctic coastal site and its potential relation to meteorological variables. Consistent seasonal peaks in $\delta^{18} \mathrm{O}, \delta \mathrm{D}, \mathrm{MSA}, \mathrm{nsSSO}_{4}^{2-}$, and $\mathrm{NO}_{3}^{-}$indicate the strong enhancement of their source during warm period, while the seasalt ions $\left(\mathrm{Na}^{+}, \mathrm{K}^{+}, \mathrm{Mg}^{2+}, \mathrm{Ca}^{2+}, \mathrm{Cl}^{-}\right.$, and totSO $\left.{ }_{4}^{2-}\right)$ show an inconsistent trend. Measured ionic concentrations reveal a dominant contribution of sea-salt aerosol deposition due to the proximity of the site to the ocean, and processes of sea ice formation. The occasional snow deposition with distinct ionic compositions was influenced by the changes in strength and pathway of storms. Monthly mean $\delta^{18} \mathrm{O}$ positively correlates with the air temperature record from AWS located in the main wind direction. Despite the shortness of the record, we proposed that the slight depletion of the isotopic composition and lowering of the snow accumulation could have been related to the cooler air temperature with decreasing open sea area (or advance of SIE). Consistency with previous studies and the positive correlation of sea-salt ions in the snow pit indicate the relative good preservation of snow layers with noticeable climate and environmental signals (e.g., changes in SIE or sea surface temperature). We note that noise can result from nonclimatic processes and thus that a more robust interpretation can be obtained from ensemble records. We report a new snow-pit record that would be compared with and support understanding of similar signals preserved in deeper ice cores in this location.

Acknowledgments. This study was supported by a Korea Polar Research Institute (KOPRI) research grant (PE21100). We are thankful to Dr. Heejin Hwang for providing data from the ICPMS analysis. Also, we express our gratitude to Dr. Kei Yoshimura for providing the results from the IsoGSM2 model. We are also grateful to the Italian PNRA (Programma Nazionale di Ricerche in Antartide) project for providing meteorological data from Lola AWS (http://www.climantartide.it) and the ERA-Interim dataset from the ECMWF.

\section{REFERENCES}

Abram, N. J., R. Mulvaney, E. W. Wolff, and M. Mudelsee, 2007: Ice core records as sea ice proxies: An evaluation from the Weddell Sea region of Antarctica. J. Geophys. Res., 112, D15101, https://doi.org/10.1029/2006JD008139.

Agosta, C., V. Favier, C. Genthon, H. Gallée, G. Krinner, J. T. M. Lenaerts, and M. R. van den Broeke, 2012: A 40-year accumulation dataset for Adelie Land, Antarctica and its application for model validation. Climate Dyn., 38, 75-86, https:// doi.org/10.1007/s00382-011-1103-4.

Anschütz, H., and Coauthors, 2011: Variation of accumulation rates over the last eight centuries on the East Antarctic Plateau derived from volcanic signals in ice cores. J. Geophys. Res., 116, D20103, https://doi.org/10.1029/2011JD015753. 
Ayling, B. F., and H. A. McGowan, 2006: Niveo-eolian sediment deposits in coastal South Victoria Land, Antarctica: Indicators of regional variability in weather and climate. Arct. Antarct. Alp. Res., 38, 313-324, https://doi.org/10.1657/1523-0430(2006) 38[313:NSDICS]2.0.CO;2.

Barbante, C., C. Turetta, A. Gambaro, G. Capodaglio, and G. Scarponi, 1998: Sources and origins of aerosols reaching Antarctica as revealed by lead concentration profiles in shallow snow. Ann. Glaciol., 27, 674-678, https://doi.org/10.3189/ 1998AoG27-1-674-678.

Becagli, S., and Coauthors, 2012: Study of present-day sources and transport processes affecting oxidized sulphur compounds in atmospheric aerosols at Dome C (Antarctica) from yearround sampling campaigns. Atmos. Environ., 52, 98-108, https://doi.org/10.1016/j.atmosenv.2011.07.053.

_- and Coauthors, 2016: Relationships linking primary production, sea ice melting, and biogenic aerosol in the Arctic. Atmos. Environ., 136, 1-15, https://doi.org/10.1016/j.atmosenv.2016.04.002.

Benassai, S., S. Becagli, R. Gragnani, O. Magand, M. Proposito, I. Fattori, R. Traversi, and R. Udisti, 2005: Sea-spray deposition in Antarctic coastal and plateau areas from ITASE traverses. Ann. Glaciol., 41, 32-40, https://doi.org/10.3189/172756405781813285.

Bertler, N. A. N., and Coauthors, 2018: The Ross Sea dipole-Temperature, snow accumulation and sea ice variability in the Ross Sea region, Antarctica, over the past 2700 years. Climate Past Discuss., 14, 193-214, https://doi.org/10.5194/cp-14-193-2018.

Bhardwaj, L. K., and T. Jindal, 2020: Persistent organic pollutants in lakes of Grovnes Peninsula at Larsemann hill area, East Antarctica. Earth Syst. Environ., 4, 349-358, https://doi.org/ 10.1007/s41748-020-00154-w.

Brimblecombe, P., 1996: Air Composition and Chemistry. Cambridge University Press, 253pp.

Broeke, M. V. N., 2008: Depth and density of the Antarctic firn layer. Arct. Antarct. Alp. Res., 40, 432-438, https://doi.org/ 10.1657/1523-0430(07-021)[BROEKE]2.0.CO;2.

Caiazzo, L., S. Becagli, D. Frosini, F. Giardi, M. Severi, R. Traversi, and R. Udisti, 2016: Spatial and temporal variability of snow chemical composition and accumulation rate at Talos Dome site (East Antarctica). Sci. Total Environ., 550, 418-430, https://doi.org/10.1016/j.scitotenv.2016.01.087.

— , and Coauthors, 2017: Prominent features in isotopic, chemical and dust stratigraphies from coastal East Antarctic ice sheet (eastern Wilkes Land). Chemosphere, 176, 273-287, https://doi.org/10.1016/j.chemosphere.2017.02.115.

Casado, M., and Coauthors, 2018: Archival of the water stable isotope signal in East Antarctic ice cores. Cryosphere Discuss., 12, 1745-1766, https://doi.org/10.5194/tc-12-1745-2018.

Cole-Dai, J., E. Mosley-Thompson, and D. Qin, 1999: Evidence of the 1991 Pinatubo volcanic eruption in South Polar snow. Chin. Sci. Bull., 44, 756-760, https://doi.org/10.1007/BF02909720.

Dansgaard, W., 1964: Stable isotopes in precipitation. Tellus, 16, 436-468, https://doi.org/10.3402/tellusa.v16i4.8993.

Dee, D. P., and Coauthors, 2011: The ERA-Interim reanalysis: Configuration and performance of the data assimilation system. Quart. J. Roy. Meteor. Soc., 137, 553-597, https://doi.org/ 10.1002/qj.828.

Delmas, R. J., S. Kirchner, J. M. Palais, and J. R. Petit, 1992: 1000 years of explosive volcanism recorded at the South Pole. Tellus, 44B, 335-350, https://doi.org/10.3402/tellusb.v44i4.15461.

Delmotte, M., V. Masson, J. Jouzel, and V. I. Morgan, 2000: A seasonal deuterium excess signal at Law Dome, coastal eastern Antarctica: A Southern Ocean signature. J Geophys. Res, 105, 7187-7197, https://doi.org/10.1029/1999JD901085.
Dibb, J. E., and S. I. Whitlow, 1996: Recent climate anomalies and their impact on snow chemistry at South Pole, 1987-1994. Geophys. Res. Lett., 23, 1115-1118, https://doi.org/10.1029/96GL01039.

Dixon, D., P. Mayewski, S. Kaspari, S. Sneed, and M. Handley, 2004: A 200 year sub-annual record of sulfate in West Antarctica, from 16 ice cores. Ann. Glaciol., 39, 545-556, https://doi.org/10.3189/172756404781814113.

Doddridge, E. W., and J. Marshall, 2017: Modulation of the seasonal cycle of Antarctic sea ice extent related to the southern annular mode. Geophys. Res. Lett., 44, 9761-9768, https:// doi.org/10.1002/2017GL074319.

Drewry, D. J., S. R. Jordan, and E. Jankowski, 1982: Measured properties of the Antarctic ice sheer: Surface configuration, ice thickness, volume and bedrock characteristics. Ann. Glaciol., 3, 83-91, https://doi.org/10.1017/S0260305500002573.

Du, Z., C. Xiao, Q. Zhang, M. J. Handley, and P. A. Mayewski, and C. Li, 2019: Relationship between the 2014-2015 Holuhraun eruption and the iron record in the East GRIP snow pit. Arct. Antarct. Alp. Res., 51, 290-298, https://doi.org/10.1080/15230430.2019.1634441.

Frezzotti, M., and Coauthors, 2004: New estimations of precipitation and surface sublimation in East Antarctica from snow accumulation measurements. Climate Dyn., 23, 803-813, https:// doi.org/10.1007/s00382-004-0462-5.

, S. Urbini, M. Proposito, C. Scarchilli, and S. Gandolfi, 2007: Spatial and temporal variability of surface mass balance near Talos Dome, East Antarctica. J. Geophys. Res., 112, F02032, https://doi.org/10.1029/2006JF000638.

Fujita, K., and O. Abe, 2006: Stable isotopes in daily precipitation at Dome Fuji, East Antarctica. Geophys. Res. Lett., 33, L18503, https://doi.org/10.1029/2006GL026936.

Goursaud, S., and Coauthors, 2017: A 60-year ice-core record of regional climate from Adélie Land, coastal Antarctica. Cryosphere, 11, 343-362, https://doi.org/10.5194/tc-11-343-2017.

_-, V. Masson-Delmotte, V. Favier, S. Preunkert, M. Legrand, B. Minster, and M. Werner, 2019: Challenges associated with the climatic interpretation of water stable isotope records from a highly resolved firn core from Adélie Land, coastal Antarctica. Cryosphere, 13, 1297-1324, https://doi.org/10.5194/tc-13-12972019.

Gragnani, R., C. Smiraglia, B. Stenni, and S. Torcini, 1998: Chemical and isotopic profiles from snow pits and shallow firn cores on Campbell Glacier, northern Victoria Land, Antarctica. Ann. Glaciol., 27, 679684, https://doi.org/10.3189/1998AoG27-1-679-684.

Han, Y., S. J. Jun, M. Miyahara, H.-G. Lee, J. Ahn, J. W. Chung, S. D. Hur, and S. B. Hong, 2015: Shallow ice-core drilling on Styx Glacier, northern Victoria Land, Antarctica in the 20142015 summer. J. Geol. Soc. Korea, 51, 343-355, https://doi.org/ 10.14770/jgsk.2015.51.3.343.

Handler, P., 1989:The effect of volcanic aerosols on global climate. J. Volcanol. Geotherm. Res., 37, 233-249, https://doi.org/ 10.1016/0377-0273(89)90081-4.

Hong, S. B., S. D. Hur, and S. M. Kim, 2012: Uncertainties of ionic species in snow pit samples determined with ion chromatography system. Anal. Sci. Technol. Korea, 25, 350-363, https:// doi.org/10.5806/AST.2012.25.6.350.

Iizuka, Y., and Coauthors, 2017: A firn densification process in the high accumulation dome of southeastern Greenland. Arct. Antarct. Alp. Res., 49, 13-27, https://doi.org/10.1657/AAAR0016-034.

Ingólfsson, Ó., H. Christian, and O. Humlum, 2003:Glacial and Climate History of the Antarctic Peninsula since the Last Glacial Maximum. Arct. Antarct. Alp. Res., 35, 175-186, https:// doi.org/10.1657/1523-0430(2003)035[0175:GACHOT]2.0.CO;2. 
Jang, Y., and Coauthors, 2019: Very old firn air linked to strong density layering at Styx Glacier, coastal Victoria Land, East Antarctica. Cryosphere, 13, 2407-2419, https://doi.org/10.5194/ tc-13-2407-2019.

Jonsell, U., M. E. Hansson, C.-M. Mörth, and P. Torssander, 2005: Sulfur isotopic signals in two shallow ice cores from Dronning Maud Land, Antarctica. Tellus, 57B, 341-350.

Jouzel, J., and V. Masson-Delmotte, 2010: Paleoclimates: What do we learn from deep ice cores? Wiley Interdiscip. Rev.: Climate Change, 1, 654-669, https://doi.org/10.1002/wcc.72.

— , R. B. Alley, and K. M. Cuffey, 1997: Validity of the temperature reconstruction from water isotopes in ice cores. J. Geophys. Res., 102, 26 471-26 487, https://doi.org/10.1029/97JC01283.

Karlöf, L., and Coauthors, 2005: Accumulation variability over a small area in east Dronning Maud Land, Antarctica, as determined from shallow firn cores and snow pits: Some implications for ice-core records. J. Glaciol., 51, 343-352, https:// doi.org/10.3189/172756505781829232.

Kreutz, K. J., and P. A. Mayewski, 1999: Spatial variability of Antarctic surfaces now glaciochemistry: Implications for paleoatmospheric circulation reconstructions. Antarct. Sci., 11, 105-118, https://doi.org/10.1017/S0954102099000140.

Kuramoto, T., K. Goto-Azuma, M. Hirabayashi, T. Miyake, H. Motoyama, D. Dahl-Jensen, and J. P. Steffensen, 2011: Seasonal variations of snow chemistry at NEEM, Greenland. Ann. Glaciol., 52, 193-200, https://doi.org/10.3189/172756411797252365.

Kwak, H., J.-H. Kang, S.-B. Hong, J. Lee, C. Chang, S.-D. Hur, and S. Hong, 2015: A study on high-resolution seasonal variations of major ionic species in recent snow near the Antarctic Jang Bogo Station. Ocean Polar Res., 37, 127-140, https://doi.org/ 10.4217/OPR.2015.37.2.127.

Lee, J., 2014: A numerical study of isotopic evolution of a seasonal snowpack and its meltwater by melting rates. Geosci. J., 18, 503-510, https://doi.org/10.1007/s12303-014-0019-5.

— X. X. Feng, A. M. Faiia, E. S. Posmentier, J. W. Kirchner, R. Osterhuber, and S. Taylor, 2010: Isotopic evolution of a seasonal snowcover and its melt by isotopic exchange between liquid water and ice. Chem. Geol., 270, 126-134, https:// doi.org/10.1016/j.chemgeo.2009.11.011.

—, S. D. Hur, H. S. Lim, and H. J. Jung, 2020: Isotopic characteristics of snow and its meltwater over the Barton Peninsula, Antarctica. Cold Reg. Sci. Technol., 173, 102997, https:// doi.org/10.1016/j.coldregions.2020.102997.

Legrand, M., and R. J. Delmas, 1986: Relative contributions of tropospheric and stratospheric sources to nitrate in Antarctic snow. Tellus, 38B, 236-249, https://doi.org/10.3402/tellusb.v38i3-4.15132.

— review. Rev. Geophys., 35, 219-243, https://doi.org/10.1029/ 96RG03527.

_ , and R. J. Delmas, 1998: Formation of $\mathrm{HCl}$ in the Antarctic atmosphere. J. Geophys. Res., 93, 7153-7168, https://doi.org/ 10.1029/JD093iD06p07153.

— C. Feniet-Saigne, E. S. Saltzman, and C. Germain, 1992: Spatial and temporal variations of methanesulfonic acid and non sea salt sulfate in Antarctic ice. J. Atmos. Chem., 14, 245 260, https://doi.org/10.1007/BF00115237.

Markle, B. R., N. A. N. Bertler, K. E. Sinclair, and S. B. Sneed, 2012: Synoptic variability in the Ross Sea region, Antarctica, as seen from back-trajectory modeling and ice core analysis. J. Geophys. Res., 117, D02113, https://doi.org/10.1029/2011JD016437.

Marshall, G. J., and D. W. J. Thompson, 2016: The signatures of large-scale patterns of atmospheric variability in Antarctic surface temperatures. J. Geophys. Res., 121, 3276-3289, https://doi.org/10.1002/2015JD024665.

- _ — , and M. R. van den Broeke, 2017: The signature of Southern Hemisphere atmospheric circulation patterns in Antarctic precipitation. Geophys. Res. Lett., 44, 11 580-11589, https://doi.org/10.1002/2017GL075998.

— , and Coauthors, 2018: The Climate Data Guide: Marshall Southern Annular Mode (SAM) Index (Station-based). NCAR, accessed 18 January 2019, https://climatedataguide.ucar.edu/ climate-data/marshall-southern-annular-mode-sam-indexstation-based.

Masson-Delmotte, V. S., and Coauthors, 2008: A review of Antarctic surface snow isotopic composition: Observations, atmospheric circulation, and isotopic modeling. J. Climate, 21, 3359-3387, https://doi.org/10.1175/2007JCLI2139.1.

Merlivat, L., and J. Jouzel, 1979: Global climatic interpretation of the deuterium-oxygen 18 relationship for precipitation. J. Geophys. Res., 84, 5029-5033, https://doi.org/10.1029/JC084iC08p05029.

Mulvaney, R., and E. W. Wolff, 1993: Evidence for winter/spring denitrification of the stratosphere in the nitrate record of Antarctic firn cores. J. Geophys. Res., 98, 5213-5220, https:// doi.org/10.1029/92JD02966.

—, D. Wagenbach, and E. W. Wolff, 1998: Postdepositional change in snowpack nitrate from observation of year-round near-surface snow in coastal Antarctica. J. Geophys. Res., 103, 11 021-11 031, https://doi.org/10.1029/97JD03624.

Nyamgerel, Y., Y. Han, S. Kim, S. Hong, J. Lee, and S. Hur, 2020: Chronological characteristics for snow accumulation on Styx Glacier in northern Victoria Land, Antarctica. J. Glaciol., 66, 916-926, https://doi.org/10.1017/jog.2020.53.

Parkinson, C. L., and D. J. Cavalieri, 2012: Antarctic sea ice variability and trends, 1979-2010. Cryosphere, 6, 871-880, https:// doi.org/10.5194/tc-6-871-2012.

Pasteris, D. R., J. R. McConnell, S. B. Das, A. S. Criscitiello, M. J. Evans, O. J. Maselli, M. Sigl, and L. Layman, 2014: Seasonally resolved ice core records from West Antarctica indicate a sea ice source of sea-salt aerosol and a biomass burning source of ammonium. J. Geophys. Res., 119, 9168-9182, https://doi.org/ 10.1002/2013JD020720.

Petit, J. R., and Coauthors, 1999: Climate and atmospheric history of the past 420,000 years from the Vostok ice core, Antarctica. Nature, 399, 429-436, https://doi.org/10.1038/20859.

Piccardi, G., R. Udisti, and F. Casella, 1994: Seasonal trends and chemical composition of snow at Terra Nova Bay (Antarctica). Int. J. Environ Anal. Chem., 55, 219-234, https://doi.org/10.1080/ 03067319408026220.

— - S. Becagli, R. Travers, and R. Udisti, 1996: Fractionating phenomena, altitude induced, on snow composition in northern Victoria Land (Antarctica). Conf. on Italian Research on Antarctic Atmosphere, Florence, Italy, Societa Italiana di Fisica, 229-245.

Pilson, M. E. Q., 2013: An Introduction to the Chemistry of the Sea. 2nd ed. Cambridge University Press, 67 pp.

Preunkert, S., B. Jourdain, M. Legrand, R. Udisti, S. Becagli, and O. Cerri, 2008: Seasonality of sulfur species (dimethylsulfide, sulfate, and methanesulfonate) in Antarctica: Inland versus coastal regions. J. Geophys. Res., 113, D15302, https://doi.org/ 10.1029/2008JD009937.

Rahaman, W., M. Thamban, and C. Laluraj, 2016: Twentiethcentury sea ice variability in the Weddell Sea and its effect on moisture transport: Evidence from a coastal East Antarctic ice core record. Holocene, 26, 338-349, https://doi.org/10.1177/ 0959683615609749 . 
Rankin, A. M., V. Auld, and E. W. Wolff, 2000: Frost flowers as a source of fractionated sea salt aerosol in the polar regions. Geophys. Res. Lett., 27, 3469-3472, https://doi.org/10.1029/2000GL011771.

Rhodes, R. H., N. A. N. Bertler, J. A. Baker, H. C. Steen-Larsen, S. B. Sneed, U. Morgenstern, and S. J. Johnsen, 2012: Little Ice Age climate and oceanic conditions of the Ross Sea, Antarctica from a coastal ice core record. Climate Past, 8, 1223-1238, https://doi.org/10.5194/cp-8-1223-2012.

Ro, S., and Coauthors, 2020: An improved ion chromatography system coupled with a melter for high-resolution ionic species reconstruction in Antarctic firn cores. Microchem. J., 159, 105377, https://doi.org/10.1016/j.microc.2020.105377.

Röthlisberger, R., and Coauthors, 2002: Nitrate in Greenland and Antarctic ice cores: A detailed description of post-depositional processes. Ann. Glaciol., 35, 209-216, https://doi.org/10.3189/ 172756402781817220.

Saltzman, E. S., I. Dioumaeva, and B. D. Finley, 2006: Glacial/ interglacial variations in methanesulfonate (MSA) in the Siple Dome ice core, West Antarctica. Geophys. Res. Lett., 33, L11811, https://doi.org/10.1029/2005GL025629.

Scarchilli, C., M. Frezzotti, and P. M. Ruti, 2011: Snow precipitation at four ice core sites in East Antarctica: Provenance, seasonality and blocking factors. Climate Dyn., 37 (9-10), 2107-2125, https://doi.org/10.1007/s00382-010-0946-4.

Severi, M., S. Becagli, E. Castellano, A. Morganti, R. Traversi, and R. Udisti, 2009: Thirty years of snow deposition at Talos Dome (northern Victoria Land, East Antarctica): Chemical profiles and climatic implications. Microchem. J., 92, 15-20, https:// doi.org/10.1016/j.microc.2008.08.004.

Sinclair, K. E., N. A. N. Bertler, and W. J. Trompetter, 2010: Synoptic controls on precipitation pathways and snow delivery to high-accumulation ice core sites in the Ross Sea region, Antarctica. J. Geophys. Res., 115, D22112, https://doi.org/ 10.1029/2010JD014383.

— — - and T. D. van Ommen, 2012: Twentieth-century surface temperature trends in the western Ross Sea, Antarctica: Evidence from a high-resolution ice core. J. Climate, 25, 36293636, https://doi.org/10.1175/JCLI-D-11-00496.1.

,-- , M. M. Bowen, and K. R. Arrigo, 2014: Twentieth Century sea-ice trends in the Ross Sea from a high-resolution, coastal ice-core record. Geophys. Res. Lett., 41, 3510-3516, https://doi.org/10.1002/2014GL059821.

Steen-Larsen, H. C., and Coauthors, 2014: What controls the isotopic composition of Greenland surface snow? Climate Past, 10, 377-392, https://doi.org/10.5194/cp-10-377-2014.

Stenni, B., and Coauthors, 1999: 200 years of isotope and chemical records in a firn core from Hercules Névé, northern Victoria Land, Antarctica. Ann. Glaciol., 29, 106-112, https://doi.org/ 10.3189/172756499781821175.

— , F. Serra, M. Frezzotti, V. Maggi, R. Traversi, S. Becagli, and R. Udisti, 2000: Snow accumulation rates in northern Victoria Land, Antarctica, by firn-core analysis. J. Glaciol., 46, 541552, https://doi.org/10.3189/172756500781832774.
—, M. Proposito, R. Gragnani, O. Flora, J. Jouzel, S. Falourd, M. Frezzotti, 2002: Eight centuries of volcanic signal and climate change at Talos Dome (East Antarctica). J. Geophys. Res., 107, 4076, https://doi.org/10.1029/2000JD000317.

_- and Coauthors, 2017: Antarctic climate variability on regional and continental scales over the last 2000 years. Climate Past, 13, 1609-1634, https://doi.org/10.5194/cp-13-1609-2017.

Traversi, R., S. Becagli, E. Castellano, O. Largiuni, A. Migliori, M. Severi, M. Frezzotti, and R. Udisti, 2004: Spatial and temporal distribution of environmental markers from coastal to plateau areas in Antarctica by firn core chemical analysis. Int. J. Environ. Anal. Chem., 84, 457-470, https://doi.org/ 10.1080/03067310310001640393.

Tuohy, A., Bertler, N., Neff, P., Edwards, R., Emanuelsson, D., Beers, T., and Mayewski, P., 2015: Transport and deposition of heavy metals in the Ross Sea Region, Antarctica. J. Geophys. Res., 120, 10 996-11 011, https://doi.org/10.1002/ 2015JD023293.

Udisti, R., 1996: Multiparametric approach for chemical dating of snow layers from Antarctica. Int. J. Environ. Anal. Chem., 63, 225-244, https://doi.org/10.1080/03067319608026268.

_, R. Traversi, G. Becagli, and G. Piccardi, 1998: Spatial distribution and seasonal pattern of biogenic sulphur compounds in snow from northern Victoria Land, Antarctica R. Ann. Glaciol., 27, 535-542, https://doi.org/10.3189/1998AoG27-1-535-542.

_- C. Barbante, E. Castellano, S. Vermigli, R. Traversi, G. Capodaglio, and G. Piccardi, 1999: Chemical characterization of a volcanic event (about AD 1500) at Styx Glacier plateau, northern Victoria Land, Antarctica. Ann. Glaciol., 29, 113-120, https://doi.org/10.3189/172756499781821265.

Uemura, R., K. Masaka, K. Fukui, Y. Iizuka, M. Hirabayashi, and H. Motoyama, 2016: Sulfur isotopic composition of surface snow along a latitudinal transect in East Antarctica. Geophys. Res. Lett., 43, 5878-5885, https://doi.org/10.1002/2016GL069482.

van Ommen, T. D., and V. Morgan, 1997: Calibrating the ice core paleothermometer using seasonality. J. Geophys. Res., 102, 9351-9357, https://doi.org/10.1029/96JD04014.

Wagenbach, D., M. Legrand, H. Fischer, F. Pichlmayer, and E. W. Wolff, 1998: Atmospheric near-surface nitrate at coastal Antarctic sites. J. Geophys. Res., 103, 11007-11020, https:// doi.org/10.1029/97JD03364.

Werner, M., J. Jouzel, V. Masson-Delmotte, and G. Lohmann, 2018: Reconciling glacial Antarctic water stable isotopes with ice sheet topography and the isotopic paleothermometer. Nat. Commun., 9, 3537, https://doi.org/10.1038/s41467-018-05430-y.

Yang, J.-W., and Coauthors, 2018: Surface temperature in twentieth century at the Styx Glacier, northern Victoria Land, Antarctica, from borehole thermometry. Geophys. Res. Lett., 45, 9834-9842, https://doi.org/10.1029/2018GL078770.

Yoshimura, K., M. Kanamitsu, D. Noone, and T. Oki, 2008: Historical isotope simulation using reanalysis atmospheric data. J. Geophys. Res., 113, D19108, https://doi.org/10.1029/ 2008JD010074. 